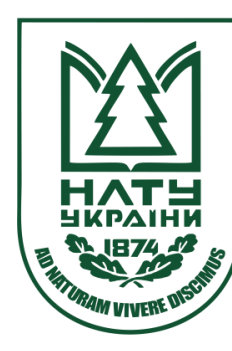

Науковий вісник НЛТУ України Scientific Bulletin of UNFU

https://nv.nltu.edu.ua

https://doi.org/10.15421/40290509

$@ \bowtie$ Correspondence author

Article received 14.05.2019 p.

Article accepted 30.05.2019 p.

M. M. Lisoviy

Удк 630*[174.754+544]

mlisovij@gmail.com

М. М. Лісовий

Національний лісотехнічний університет України, м. Львів, Украӥна

\title{
ВПЛИВ СТИМУЛЯТОРІВ РОСТУ НА ІНІЦІАЦІЮ ЕКСПЛАНТІВ THUJA OCCIDENTALIS L. B УMOBAX IN VITRO
}

На основі критичного аналізу літературних джерел встановлено потребу проведення поглибленого дослідження процесу росту експлантів Thuja occidentalis L. на етапі ініціації під час мікроклонального розмноження в умовах in vitro під впливом різних стимуляторів росту. Розглянуто застосовану методику виконання експериментальних досліджень. Проведено тестування трьох рецептів базових живильних середовищ: Murashige and Skoog medium (MS), Risser and White medium (RW) та Litvay medium (LM) і встановлено, що для мікроклонування досліджуваного виду оптимальним $\epsilon$ RW. Визначено вплив синтетичних фітогормонів ауксинового (2,4-D та НОК) і цитокінінового (БАП) типу на успішність проходження етапу ініціації експлантів Thuja occidentalis L. Досліджено явище утворення калюсної тканини в експлантів під впливом різних ростових речовин. Виконано якісну оцінку ініціації експлантів, на основі якої проведено їхній поділ на три групи: "незадовільна ініціація", "задовільна ініціація" та "добра ініціація", залежно від збільшення лінійних розмірів рослинного матеріалу. Встановлено, що оптимальним живильним середовищем для ініціації росту досліджуваного виду є RW, модифіковане 0,3 мг/л (2,4D) $+0,5 \mathrm{мг/л} \mathrm{(НОК)}+0,2$ мг/л (БАП).

Ключові слова: Thuja occidentalis L.; in vitro; стимулятор росту; ініціація.

Вступ. Мікроклональне розмноження рослин в умовах in vitro характеризується низкою істотних переваг, порівняно із традиційним (генеративним) способом розмноження, а тому є важливим, актуальним та перспективним сучасним засобом забезпечення збереження біорізноманіття (Belokurova, 2010; Kushnir \& Sarnatska, 2005). Це зумовлено можливістю отримання практично необмеженої кількості одиниць клонів із невеликої кількості вихідного рослинного матеріалу під час забезпечення відтворення генетично однорідних клонів (Kalinin, Kushnir \& Sarnatckaia, 1992; Marchuk \& Kyryliuk, 2008; Melnychuk et al., 2011; Harry et al., 1987).

Відомо, що успіх усіх етапів мікроклонального розмноження рослин, зокрема ініціації експлантів, залежить від правильного підбору всіх компонентів, з яких складається живильне середовище (Musiienko \& Paniuta, 2005). Зокрема, успішний ріст та диференціація ізольованих рослинних клітин або тканин на живильному середовищі можливі тільки за наявності у ньому стимуляторів (регуляторів) росту, які є штучно синтезованими аналогами фітогормонів та основною функцією яких $€$ регулювання проходження процесів онтогенезу в рослинних організмів (Belokurova, 2010; Kalinin, Kushnir \& Sarnatckaia, 1992; Rastorguev, 2009; Rudyshyn, 1998). Саме тому з'ясування впливу ростових речовин на процеси ініціації експлантів $\epsilon$ актуальним завданням.

Огляд літературних джерел. Як об'єкт досліджень 3 мікроклонування обрали Thuja occidentalis L., яка $€$ однією із найпоширеніших рослин в озелененні населених пунктів. Досліджуваний вид $є$ вічнозеленим, стій- ким до урбанізованих умов таксоном, якому притаманний значний генетичний поліморфізм за різними морфологічними ознаками (габітусом крони, кольором хвої тощо), що і зумовлює його цінність (Brodovych \& Brodovych, 1979; Zaiachuk, 2008; Kushnir, Mykhailiuk \& Matskevych, 2017; Lisovyi \& Huz, 2015).

Аналіз ретроспективи досліджень із розмноження в умовах in vitro Thuja occidentalis L. показав наявність вкрай обмеженої кількості експериментальних робіт. Зокрема, Indra S. Harry та ін. (1987 р.) досліджували проходження соматичного ембріогенезу в туї західної в умовах in vitro. Початкову індукцію зародків було отримано після культивуванні експлантів протягом 2025 діб на живильному середовищі Quoirin and Le Poivre iз додаванням BA та 2-ізопентиладеніну. Проте активний розвиток зародків спостерігали на тому ж середовищі без фітогормонів. Автори зазначають, що цим способом можна отримати понад 250 рослин 3 одного ембріона (Harry et al., 1987). Вчені К. А. Nour та Т. А. Thorpe (1993 р.) у своїх дослідженнях, способом ретельного підбору компонентів живильного середовища, отримали від 10 до 14 пазушних пагонів після культивування експлантів туї західної на живильному середовищі 1/2 Quiorin and Le Poivre із додаванням до нього 10 мМ стерилізованого зеатину (Nour \& Thorpe, 1993). Грунтовні дослідження особливостей мікроклонування туї західної виконали вчені М. H. Kabir, P. K. Roy та Golam Ahmed (2006 р.). Як експланти застосували апікальні пагони Thuja occidentalis L. довжиною близько 2 см, які стерилізували протічною водою 3 миючим за-

Інформація про авторів:

Лісовий Микола Миколайович, д-р с.-г. наук, доцент, кафедра лісових культур і лісової селекції. Email: mlisovij@gmail.com Цитування за ДСтУ: Лісовий М. М. Вплив стимуляторів росту на ініціацію експлантів Thuja Occidentalis L. в умовах in vitro. Науковий вісник НлтУ України. 2019, т. 29, № 5. С. 47-50.

Citation APA: Lisoviy, M. M. (2019). Influence of growth stimulants on the initiation explants of Thuja Occidentalis L. under in vitro conditions. Scientific Bulletin of UNFU, 29(5), 47-50. https://doi.org/10.15421/40290509 
собом (15 хв), 40 \%-м препаратом "Clorox" (5 хв) та $0,1 \%$-м розчином хлориду ртуті (5 хв), після чого промивали рослинний матеріал стерильною дистильованою водою. Експланти пасажували на живильне середовище MS із додаванням різної кількості стимуляторів росту (BA, Kn та NAA). Для укорінення застосовували середовище 1/2 MS, модифіковане речовинами IBA, IAA та NAA. Вчені досягли таких результатів: середня кількість пагонів на експланти $-6,57^{ \pm 0,45}$; середня довжина пагонів $-4,5^{ \pm 0,27} \mathrm{~cm}$; середня кількість коренів на один клон - 3,92 $2^{ \pm 0,28}$; середня довжина коренів $3,64^{ \pm 0,38}$ см (Kabir, Roy \& Golam, 2006). Також, цією ж тематикою займались В. М. Кріт, В. В. Мацкевич (2015 р.) (Krit \& Matskevych, 2017) та Н. Б. Кушнір, Д. В. Михайлюк, В. В. Мацкевич (2016 р.) (Kushnir, Mykhailiuk \& Matskevych, 2017). У цитованих джерелах немає інформації про особливості проходження ініціації експлантів досліджуваного виду, від якої залежить результативність подальших етапів мікроклонування, зокрема під впливом різних регуляторів росту (Kalinichenko, 2003; Tretiakova et al., 2008).

Матеріали та методи дослідження. Усі експериментальні дослідження проводили в лабораторії культури тканин кафедри лісових культур і лісової селекції НЛТУ України. Як експланти застосовували частинки верхівок пагонів довжиною 4-6 мм, які заготовляли 3 молодих рослин віком 4-7 років. У наших дослідженнях апробували три типи живильних середовищ Murashige and Skoog medium (MS), Risser and White medium (RW) тa Litvay Medium (LM) (Kalinin, Kushnir \& Sarnatckaia, 1992; Kushnir \& Sarnatska, 2005; Lisovyi, 2017). Культивування експлантів проводили в культуральній кімнаті за температури повітря $20-22{ }^{\circ} \mathrm{C}$, відносної вологості повітря 30-35\% та 16-годинного фотоперіоду (2,83,0 кЛк). Спостереження за процесом ініціації експлантів виконували протягом 40-50 діб.

На етапі встановлення оптимального базового рецепту живильного середовища, до ініційованих експлантів відносили ті, які зовнішньо виглядали неушкодженими, були однотонного кольору та дещо збільшили свої розміри. Для якісної оцінки отриманих результатів ініціації експланти класифікували на три групи: "незадовільна ініціація" - експланти життєздатні, збільшились лінійно орієнтовно у 2-3 рази; "задовільна ініціація" - експланти життєздатні, збільшились лінійно орієнтовно у 4-5 рази; "добра ініціація" - експланти життездатні, збільшились лінійно у понад 5 разів.

Результати дослідження. Склад живильного середовища безпосередньо впливає на успішність росту та розвитку рослинного матеріалу в культурі in vitro, ocкільки він є єдиним джерелом усіх необхідних речовин для клонів. Із метою підбору базового рецепту живильного середовища пасажували простерилізовані експланти на три їх типи (MS, LM та RW), які модифікували однаково, додаючи 0,1 мг/л (2,4-D)+0,1 мг/л (БАП). Внаслідок проведених експериментальних досліджень встановили, що на живильному середовищі MS спостерігали $61,1 \%$ ініційованих експлантів, на LM - 55,6 \%, а на RW ініціація була найкращою і становила 63,3 \%. Саме тому останній варіант й обрали для виконання подальших робіт.

Із метою підвищення кількості ініційованих експлантів до живильного середовища RW додавали стимулятори 2,4-D i HOK (0,3 та 0,5 мг/л) та БАП (0,2 та
0,3 мг/л) у всіх можливих поєднаннях та комбінаціях. Відомо, що в незначних дозах регулятори росту ауксинової та цитокінінової природи стимулюють, тією чи іншою мірою ріст та розвиток вегетативних органів, а також можуть ініціювати калюсогенез експлантів в умовах in vitro (Kalinin, Kushnir \& Sarnatckaia, 1992; Kushnir \& Sarnatska, 2005; Musiienko \& Paniuta, 2005). Тому ми окремо дослідили явище утворення калюсної тканини під впливом різних ростових речовин та його вплив на ріст експлантів (таблиця).

Таблиця. Показники ініціації експлантів Thuja occidentalis L.

\begin{tabular}{|c|c|c|c|c|c|}
\multirow{2}{*}{$\begin{array}{c}\text { № } \\
3 / \Pi\end{array}$} & \multicolumn{2}{|c|}{\begin{tabular}{c} 
Регулятори росту, застосовані \\
для модифікації середовища \\
\cline { 2 - 4 }
\end{tabular}} & $\begin{array}{c}\text { Частка іні- } \\
\text { ційованих } \\
\text { експлан- } \\
\text { тів, \% }\end{array}$ & $\begin{array}{c}\text { Частка } \\
\text { експлантів 3 } \\
\text { калюсом (i3 } \\
\text { них), \% }\end{array}$ \\
\hline 1 & 0,3 & 0,3 & 0,2 & 86,7 & 3,8 \\
\hline 2 & 0,5 & 0,3 & 0,2 & 80,0 & 0,0 \\
\hline 3 & 0,3 & 0,5 & 0,2 & 73,3 & 9,1 \\
\hline 4 & 0,5 & 0,5 & 0,2 & 73,3 & 4,5 \\
\hline 5 & 0,3 & 0,3 & 0,3 & 83,3 & 12,0 \\
\hline 6 & 0,5 & 0,3 & 0,3 & 76,7 & 8,7 \\
\hline 7 & 0,3 & - & 0,3 & 56,7 & 70,6 \\
\hline 8 & - & 0,3 & 0,3 & 60,0 & 61,1 \\
\hline 9 & 0,5 & - & 0,3 & 40,0 & 100,0 \\
\hline 10 & - & 0,5 & 0,3 & 46,7 & 78,6 \\
\hline
\end{tabular}

Практично у всіх варіантах спостерігали досить значне калюсоутворення в експлантів досліджуваного виду (див. таблиця). Отримані результати свідчать, що тільки в одному варіанті досліду (№ 2), із дещо збільшеним вмістом стимулятора росту $2,4-\mathrm{D}$ та застосуванням усіх трьох синтетичних фітогормонів, спостерігали активний ріст експлантів, які не утворювали калюсу (80,0 \% випадків), що, на нашу думку, швидше можна вважати випадковістю. Проте, незважаючи на масове утворення калюсу у вихідних експлантів Thuja occidentalis, вони продовжували активно збільшувати свої лінійні розміри (рис. 1).

Щодо розподілу експлантів за якісними показниками ініціації, то найбільше рослинного матеріалу з доброю оцінкою (100 \%) відзначено у варіанті досліду № 2, де застосовано максимальну кількість речовини 2,4-D у поєднанні з мінімальними дозами інших стимуляторів (рис. 2). Високі показники ініціації фіксували за мінімальної концентрації стимуляторів ауксинової природи і БАП (варіант № 1) та за підвищеного вмісту НОК (варіант № 3): 96,2-95,5 \% добре і 3,8-4,5 \% задовільно ініційованих експлантів. У випадках підвищення вмісту БАП у живильному середовищі (варіанти № 5, 6), відзначили зниження досліджуваних показників: 73,980,0 \% експлантів із доброю ініціацією; 8,0-13,0 \% - задовільною та 12,0-13,0 \% - незадовільною.

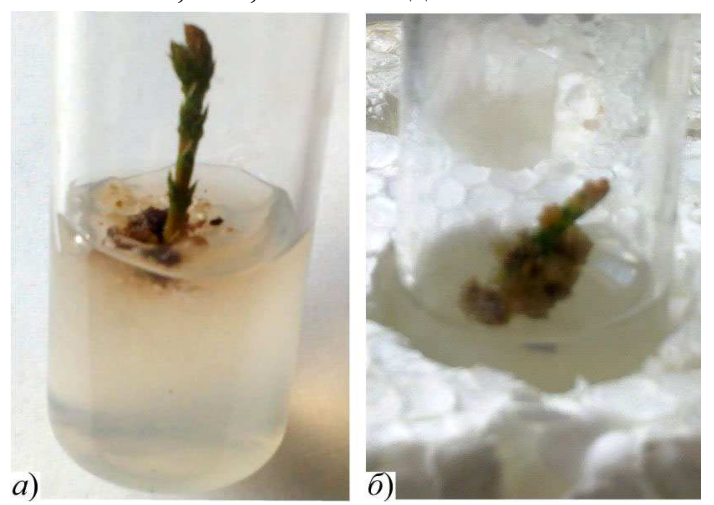

Pис. 1. Ініційований експлант Thuja occidentalis L.: a) без калюсної тканини; б) із калюсною тканиною 


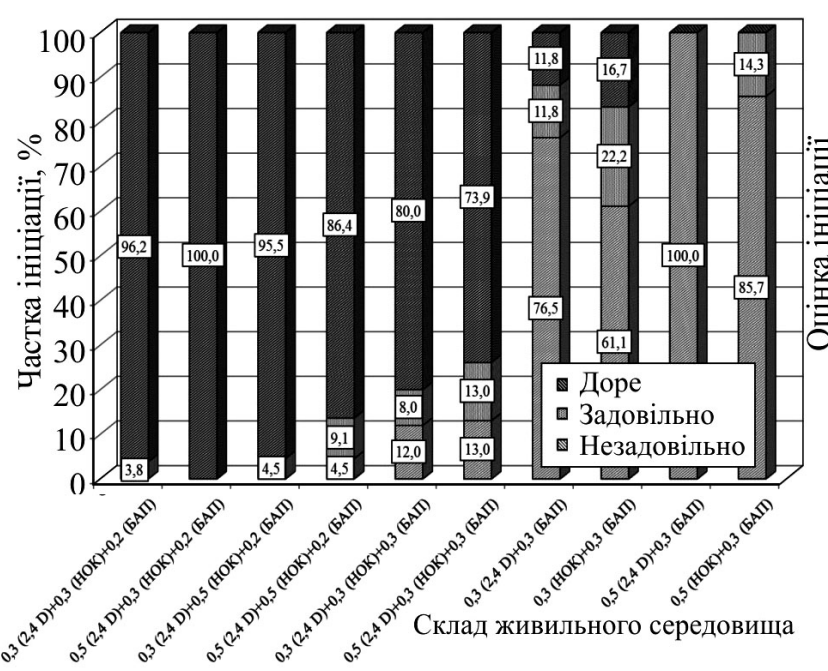

Рис. 2. Розподіл експлантів туї західної за якісними показниками ініціації

Застосування тільки одного стимулятора ауксинового типу спричинило найнижчі результати (варіанти 710). Зокрема, найгірше ініціювали експланти внаслідок застосування максимальної кількості 2,4-D - 100 \% незадовільної ініціації рослинного матеріалу.

Висновки. Проведені дослідження свідчать про значний вплив таких параметрів живильного середовища, як концентрація та комбінація стимуляторів росту ауксинового та цитокінінового типів на особливості проходження процесу ініціації експлантів Thuja occidentalis L. під час розмноження in vitro. Зокрема, підвищення вмісту речовини БАП у живильному середовищі спричиняє зменшення кількості експлантів із доброю ініціацією. Поєднання стимулятора росту цитокінінового типу тільки 3 одним ауксинового типу забезпечує найнижчі якісні показники ініціації. Загалом, отримані результати дали змогу дійти висновку, що оптимальними умовами ініціації експлантів Thuja occidentalis L. характеризується живильне середовище RW, модифіковане 0,3 мг/л (2,4-D)+0,5 мг/л (НОК)+0,2 мг/л (БАП).

\section{Перелік використаних джерел}

Belokurova, V. B. (2010). Metody biotekhnolohii v systemi zakhodiv zi zberezhennia bioriznomanittia roslyn. Tsytolohyia y henetyka, 3 , 36-52. [In Ukrainian].

Brodovych, T. M., \& Brodovych, M. M. (1979). Dereva i chaharnyky zakhodu URSR. Lviv: Higher school, 251 p. [In Ukrainian].
Harry, I. S., Thompson, M. R., Lu Chin-Yi, \& Thorpe, T. A. (1987). In vitro plantlet formation from embryonic explants of eastern white cedar (Thuja occidentalis L.). Tree Physiol, 3(3), 273-283.

Kabir, M. H., Roy, P. K., \& Golam Ahmed. (2006). In vitro Propagation of Thuja occidentalis. Through Apical Shoot Culture Plant Tissue Cult. \& Biotech, 16(1), 5-9.

Kalinichenko, O. A. (2003). Dekoratyvna dendrolohiia. Kyiv: Higher school, 199 p. [In Ukrainian].

Kalinin, F. L., Kushnir, G. P., \& Sarnatckaia, V. V. (1992). Tekhnologiia mikroklonalnogo razmnozheniia rastenii. Kyiv: Scientific thought, 232 p. [In Russian].

Krit, V. M., \& Matskevych, V. V. (2017). Vplyv donoriv eksplantiv na mikroklonalne rozmnozhennia Thuja occidentalis Smaragd. Retrieved from: http://www.btsau.kiev.ua/sites/default/files/tezy/stud roslin tezy 2015.pdf(Date of treatment: 19.03.2017). [In Ukrainian].

Kushnir, H. P., \& Sarnatska, V. V. (2005). Mikroklonalne rozmnozhennia roslyn. Kyiv: Scientific thought, 450 p. [In Ukrainian].

Kushnir, N. B., Mykhailiuk, D. V., \& Matskevych, V. V. (2017). Zmina fotosyntezuiuchykh orhaniv tui $\mathrm{v}$ umovakh in vitro ta ex vitro. Retrieved from: http://www.btsau.net.ua/sites/default/files/tezy/tezy agro stud 2016.pdf 2016). (Date of treatment: 19.03.2017). [In Ukrainian].

Lisovyi, M. M. (2017). Some features of obtaining aseptic culture of thuja occidentalis L. under In Vitro conditions. Scientific Bulletin of UNFU, 27(9), 27-29. https://doi.org/10.15421/40270905

Lisovyi, M. M., \& Huz, M. M. (2015). Polimorfizm ta osoblyvosti vehetatyvnoho rozmnozhennia zhyvtsiuvanniam dekoratyvnykh form Thuja occidentalis L. Lisivnytstvo i ahrolisomelioratsiia, 126, 132138. [In Ukrainian].

Marchuk, O. O., \& Kyryliuk, V. I. (2008). Zberezhennia ta rozmnozhennia tsinnykh henotypiv in vitro. Naukovi dopovidi NAU, 4(12), 10-21. [In Ukrainian].

Melnychuk, M. D., Hryhoriuk, I. P., Novak, T. V., Kliachenko, O. L., et al. (2011). Biotekhnolohiia roslyn. Kyiv: Vydavnychyi tsentr NUBiP Ukrainy, 216 p. [In Ukrainian].

Musiienko, M. M., \& Paniuta, O. O. (2005). Biotekhnolohiia roslyn. Kyiv: VPTs "Kyivskyi universytet", 114 p. [In Ukrainian].

Nour, K. A., \& Thorpe, T. A. (1993). In vitro shoot multiplication of eastern white cedar (Thuja occidentalis). In vitro Cell Dev Biol Plant, 29, 65-71.

Rastorguev, S. L. (2009). Kultura izolirovannykh tkanei i organov $v$ selektcii plodovikh rastenii. Michurinsk: Michurinsky State Agrarian University, 170 p. [In Russian].

Rudyshyn, S. D. (1998). Osnovy biotekhnolohii roslyn. Vinnytsia, 224 p. [In Ukrainian].

Tretiakova, I. N., Ivanitckaia, A. S., Bursukova, A. V., Izhboldina, M. V., \& Noskova, N. E. (2008). Biotekhnologii khvoinykh in vitro. Problemy i perspektivy. Faktory eksperymentalnoi evoliutsii orhanizmiv, 5, 267-271. [In Russian].

Zaiachuk, V. Ya. (2008). Dendrolohiia. Lviv: Apriori, 656 p. [In Ukrainian].

M. M. Lisoviy

Ukrainian National Forestry University, Lviv, Ukraine

\section{INFLUENCE OF GROWTH STIMULANTS ON THE INITIATION EXPLANTS OF THUJA OCCIDENTALIS L. UNDER IN VITRO CONDITIONS}

Micropropagation of plants under in vitro conditions is characterized by a number of advantages over other methods, and is therefore an important and promising modern means of biodiversity conservation. The success of micropropagation, including the initiation of explants, depends on the proper selection of all components from which the nutrient medium forms. We have chosen Thuja occidentalis L. as a research object, which is one of the most widespread plants in the landscaping of settlements, because it is characterized by significant polymorphism. An analysis of literary sources in relation to research topics shows that there is a limited number of experimental works in the field of the study. All experimental studies were carried out at the Laboratory of Culture of Tissues of the Forest Crop Department and Forest Selection of UNFU in accordance with generally accepted biotechnological methods. As explants, we used the upper parts of the shoots of 4-6 mm long, which were harvested from young plants (4-7 years old). For qualitative evaluation of the results of initiation, the explants were classified into three groups: unsatisfactory initiation - the explants were viable, increased linearly approximately 2-3 times, satisfactory initiation - the explants were viable, increased linearly approximately by 4-5 times; good initiation - the explants are viable, increased linearly in more than 5 times. Explants were planted in three types in order to choose a better base recipe for a nutrient medium (MS, RW, LM) with $0.1 \mathrm{mg} / \mathrm{l}(2.4-\mathrm{D})+0.1 \mathrm{mg} / 1$ (BAP). It is established that for Thuja occidentalis L. the RW medium is optimal, which provided initiation of $63.3 \%$ of explants. Stimulators $2.4-$ 
D and NAA ( 0.3 and $0.5 \mathrm{mg} / \mathrm{l})$ and BAP $(0.2$ and $0.3 \mathrm{mg} / \mathrm{l})$ in different combinations were added to the RW medium to increase the initiation of explants. Virtually all variants of research observed a significant formation of callus in explants, but this phenomenon did not affect the active increase in their size. It was also found that the highest amount of plant material with a good initiation $(100 \%)$ had been noted in the experimental version where the maximum tested amount of the substance $2.4-\mathrm{D}(0.3 \mathrm{mg} / \mathrm{l}) \mathrm{in} \mathrm{combi}-$ nation with the minimum doses of other stimulants $(0.5 \mathrm{mg} / \mathrm{l} \mathrm{NAA}$ and $0.2 \mathrm{mg} / \mathrm{L} \mathrm{BAP})$. In the case of an increase in the content of BAP in the nutrient medium, we observed decline in the studied parameters. As a result of the experimental studies, we should conclude that the concentration and the combination of growth promoters of auxin and cytokinin types have a significant effect on the initiation of Thuja occidentalis L. explants during micropropagation under in vitro conditions. The obtained results allow concluding that the optimum nutrient medium for the initiation of explants of the studied species is RW, modified $0.3 \mathrm{mg} / 1$ (2.4-D) + $0.5 \mathrm{mg} / \mathrm{l}(\mathrm{NAA})+0.2 \mathrm{mg} / \mathrm{l}(\mathrm{BAP})$.

Keywords: Thuja occidentalis L.; in vitro; growth stimulator; initiation. 